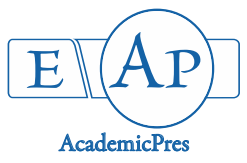

Onoja RI et al. (2020)
Notulae Scientia Biologicae 12(3):568-577
DOI: $10.15835 /$ nsb12310765
Research Article

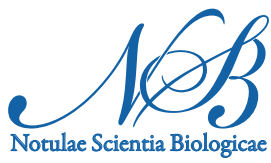

\title{
Possible ameliorative effects of hydromethanol extract of Thymus vulgaris on cadmium induced hepatorenal toxicity in rats
}

\author{
Remigius I. ONOJA ${ }^{1 *}$, Chinwe U. CHUKWUDI ${ }^{1}$, Nnenna T. \\ EMEJUO $^{1}$, Hillary E. UGWUANYI², Emmanuel U. UGWUEZE ${ }^{1}$ \\ ${ }^{1}$ University of Nigeria, Nsukka, Faculty of Veterinary Medicine, Department of Veterinary Pathology and Microbiology, Nsukka, \\ Nigeria; remigius.onoja@unn.edu.ng(*'corresponding author); chinwe.chukwudi@unn.edu.ng; tochi.emejuo@unn.edu.ng; \\ remiwrites@yahoo.com \\ ${ }^{2}$ University of Nigeria, Nsukka, Faculty of Veterinary Medicine, Department of Veterinary Physiology and Pharmacology, Nsukka, \\ Nigeria; emeka.ugwuanyi@unn.edu.ng
}

\begin{abstract}
This study evaluated the possible ameliorative effect of hydromethanol extract of Thymus vulgaris on hepatorenal toxicity induced by cadmium in male rats. The experimental animals were divided into four groups and treated as follows: A (control $-0.5 \mathrm{ml}$ of $2 \%$ tween 80 in distilled water per os) for 3 weeks and a single subcutaneous dose of phosphate buffered saline, B (single subcutaneous dose of cadmium in phosphate buffered saline at $3 \mathrm{mg} / \mathrm{kg}$ ); C ( $500 \mathrm{mg} / \mathrm{kg}$ extract per os daily for 3 weeks) and D (single subcutaneous dose of cadmium in phosphate buffered saline at $3 \mathrm{mg} / \mathrm{kg}+500 \mathrm{mg} / \mathrm{kg}$ extract per os daily for 3 weeks). Cadmium administration resulted in suppression of erythrocyte count, hemoglobin concentration, packed cell volume, an elevated total leucocyte count with associated neutrophilia which improved with extract administration. Levels of serum alanine aminotransferase, aspartate aminotransferase and alkaline phosphatase, creatinine and total bilirubin concentration increased with decrease in total serum protein and albumin in cadmium treated group B compared to control group A, group C (extract only) and cadmium plus extract treated group D. Cadmium led to a reduction in catalase and superoxide dismutase activities with increase in the level of malondialdehyde. However, co-administration of extract with cadmium in group D reduced lipid peroxidation and oxidative stress induced by cadmium. Histopathological examination of cadmium treated groups showed moderate vacuolar degeneration in the liver and degeneration of the kidney tubules which were ameliorated following co-administration with extract. This study shows that Thymus vulgaris extract has a potential protective effect against cadmium induced hepato-renal injury through the suppression of oxidative stress.
\end{abstract}

Keywords: antioxidant; cadmium; kidney; liver; Thymus vulgaris

\section{Introduction}

Cadmium $(\mathrm{Cd})$ is an environmental and industrial pollutant with high toxicity and carcinogenic activity (IARC, 2012). It is widely used in industry, but affects human health through occupational and environmental exposure. Humans are primarily exposed to cadmium from contaminated food and water, smoking and industrial emissions (El-Habit and Abdel Moneim, 2014). This pollutant gets into the body of 
both man and animals to accumulate in various organs such as the kidney, liver, testes, pancreas, thyroid, salivary glands, bone and central nervous system (Huff et al., 2007; Nordberg et al., 2014). In these organs, cadmium causes severe pathology ranging from cellular degeneration and necrosis to carcinogenic effects. The main target organs for cadmium are the testes, liver and kidney.

In the liver, cadmium causes liver failure associated with hepatocyte degeneration, focal necrosis, changes in the liver functional biomarkers and fat deposition (El-Refaiy and Eissa, 2013). Cadmium induced renal damage results in glomerular swelling and increased urinary space (Mouihs and Thevenod, 2010). Previous studies have linked the toxic effects of cadmium to oxidative stress, since it can alter the antioxidant defense system in several tissues, causing a decrease in the activity of antioxidant enzymes and a change in cell membrane structure through increased lipid peroxidation (Dzobo and Naik, 2013; Kumar et al., 2019). Animals and humans that inhabit industrial areas where cadmium is used for manufacturing certain products are vulnerable to accidental cadmium exposure. Thus, various options are employed in the management and treatment of cadmium toxicity in both animals and humans with little or no success (Rafati Rahimzadeh et al., 2017).

In recent years, numerous scientific studies have been undertaken to support the dietary intake of antioxidant - rich food which can reduce the risk of various disease and also protect the tissues and organs from vulnerability to various environmental hazardous substances like cadmium. The plant Thymus vulgaris $\mathrm{L}$. (Lamiaceae), is known to contain essential oils which consist of carvacrol, linalool and thymol (Satyal et al., 2016). The plant leave extract is reported to have immunomodulatory and anti-inflammatory properties (Ocaña and Reglero, 2012), as well as antioxidant and free radical scavenging effects (Vigo et al., 2004; ElNekeety et al., 2011). Therefore, this study was designed to evaluate the possible ameliorative effects of hydromethanol extract of Thymus vulgaris (HMETV) on cadmium-induced hepatorenal toxicity in rats.

\section{Materials and Methods}

\section{Chemicals}

Cadmium chloride ( $\mathrm{CdCl}_{2}-99 \%$ pure) was purchased from Sigma Aldrich Chemicals Co. (St. Louis, Mo, USA). All chemicals and kit reagents used were of analytical grade and obtained from commercial supplies.

\section{Preparation of plant material}

The leaves of T. vulgaris plant used in this study were purchased from a local market in Nsukka, Nigeria and identified by Mr. A. Ozioko, a botanist at the Department of Plant Science and Biotechnology, University of Nigeria, Nsukka. The leaves were carefully washed with tap water to remove dust and other impurities and dried under shade for about 10 days, after which they were ground to powder using a grinding machine. The dried ground powder of $T$. vulgaris was soaked in $70 \%$ methanol for 3 days after which the extract was evaporated using a rotary evaporator (Daud et al., 2017). The hydromethanol extract of Thymus vulgaris (HMETV) obtained was stored in a container at $4^{\circ} \mathrm{C}$ and reconstituted with $2 \%$ tween 80 in distilled water prior to administration.

\section{Acute toxicity study of the HMETV}

This was done to evaluate the acute toxicity of HMETV according to the Organization of Economic Cooperation and Development (OECD) guideline 423 (OECD, 2003). The LD50 was found to be greater than $5000 \mathrm{mg} / \mathrm{kg}$, thus oral dose of $500 \mathrm{mg} / \mathrm{kg}$ was selected for the HMETV treated groups.

\section{Experimental animals}

A total of twenty 10-12 weeks old healthy Sprague-Dawley outbred male albino rats (Rattus norvegicus) weighing between 150-200 g were purchased from the Experimental Animal Unit of the Zoological Garden, University of Nigeria, Nsukka. The rats were housed in standard metal cages with wood shavings as bedding in 
the Experimental Animal Unit of the Department of Veterinary Pathology and Microbiology, University of Nigeria, Nsukka and acclimatized at a temperature of $25 \pm 4^{\circ} \mathrm{C}$ and relative humidity of $65 \pm 5 \%$ with an alternating $12 \mathrm{~h}$ light and dark cycle for two weeks. They were fed growers diet (Top Feeds Ltd, Sapele, Nigeria) and given tap water ad libitum.

\section{Experimental design}

The experiment was conducted in compliance with the Ethics and Regulations Guiding the Use of Research Animals as approved by the University of Nigeria, Nsukka (FVM2020/117) based on the experimental protocols as directed by the National Institute of Health Guide for Care and Use of Laboratory Animals (NRC, 2011). After an acclimatization period of 2 weeks, the rats were randomly divided into four groups of five rats each based on body weight and treated as follows: A (control group given $0.5 \mathrm{ml}$ of $2 \%$ tween 80 in distilled water per os (P.O) daily for 3 weeks and single subcutaneous dose of phosphate buffered saline (PBS); B (single subcutaneous dose of cadmium dissolved in phosphate buffered saline (PBS) at $3 \mathrm{mg} / \mathrm{kg}$ ); C (HMETV $500 \mathrm{mg} / \mathrm{kg}$ P.O daily for 3 weeks) and D (single subcutaneous dose of cadmium at $3 \mathrm{mg} / \mathrm{kg}+$ HMETV $500 \mathrm{mg} / \mathrm{kg}$ P.O daily for 3 weeks). The dose of cadmium used and the duration of study was based on previous reports (Ponnusamy and Pari, 2011).

\section{Animal sacrifice and sampling}

At the end of the experiment, the rats were fasted overnight and $4 \mathrm{~mL}$ of blood was collected in the morning via the orbital plexus into two sets of sample bottles, one with EDTA and another plain sample bottle in order to obtain serum, after euthanasia by intraperitoneal injection of $90 \mathrm{mg} / \mathrm{kg}$ body weight ketamine hydrochloride (Laborate Pharmaceutical, India) and $5 \mathrm{mg} / \mathrm{kg}$ body weight xylazine-Kepro Holland (Zarei and Shahrooz, 2019). Blood in the plain sample bottles were centrifuged (1000g for $10 \mathrm{~min}$ ) and serum collected for biochemical analyses. Thereafter, the rats were dissected and organs of interest such as the kidney and liver were harvested for antioxidant enzyme activity, lipid peroxidation assay and histopathology.

\section{Hematological analyses}

The packed cell volume (PCV) was determined using the microhaematocrit method while the erythrocyte count (EC) and total leucocyte count (TLC) were determined using the haemocytometer method (Thrall and Weiser, 2002). Differential leucocyte counts (DLC) was performed using the stained blood film (Thrall and Weiser, 2002), while haemoglobin concentration $(\mathrm{Hb})$ was determined using the Drabkin's reagent assay method for $\mathrm{Hb}$ concentration (Higgins et al., 2008a)

\section{Serum biochemical analyses}

The determination of total serum protein was performed using the direct biuret method for the in vitro determination of total protein in serum (Johnson, 2008), while albumin level was assayed using the Bromocresol green method (Doumas et al., 1971). Determination of serum creatinine was based on the modified Jaffe method (Blass et al., 1974), for the in vitro determination of creatinine in serum using the Quimica Clinica Applicada (QCA) Creatinine test kit (QCA, Spain). Aspartate Aminotransferase (AST), Alanine Aminotransferase (ALT) and Alkaline Phosphatase (ALP) activity was assessed using the standard method (Colville, 2002). Catalase (CAT) and Superoxide dismutase (SOD) activity was estimated according to standard methods (Nishikimi, 1972; Hadwan, 2018). Lipid peroxidation biomarker, malondyaldehyde (MDA) was measured by spectrophotometric method as described previously (Ohkawa, 1979).

\section{Histopathological examination}

The liver and kidney tissues were dehydrated in graded concentrations of ethanol, cleared in xylene, and embedded in paraffin wax. Five-micrometer thick sections were cut, mounted on glass slides, and stained with 
haematoxylin and eosin for light microscopy (Bancroft and Gamble, 2002). Photomicrographs were captured using a Moticam Image plus 2.0 digital cameras (Motic China Group Ltd. 1999-2004).

\section{Statistical analysis}

Statistical analysis of the data was done using SPSS statistics software. Multiple comparisons were performed using one-way ANOVA followed by Post-hoc Test ( $p$ value $<0.05)$. Values were expressed as means \pm standard error of the mean (S.E.M).

\section{Results}

Hematological analyses showed a decrease in packed cell volume, hemoglobin concentration and erythrocyte count in cadmium treated group B rats compared to the control (group A), group C (HMETV only) and HMETV plus cadmium treated group $\mathrm{D}$ which were higher. There was also an increase in total leucocyte count associated with neutrophilia in cadmium treated group B compared to the control and HMETV only treated group $C$ which reduced following treatment with HMETV plus cadmium in group D (Table 1). Serum activities of alanine aminotransferase, aspartate aminotransferase, alkaline phosphatase were higher in cadmium treated group B compared to other groups while there was a significant $(p<0.05)$ increase in total bilirubin in cadmium treated group B compared to the control, HMETV treated group C and HMETV plus cadmium treated group $\mathrm{D}$, but total serum protein and albumin decreased with increased creatinine levels in cadmium treated group B compared to the control, HMETV treated group $C$ and HMETV plus cadmium treated group D (Table 1).

Table1. Hematological and serum biochemical parameters (mean \pm SEM) of the experimental groups of rats

\begin{tabular}{|c|c|c|c|c|}
\hline Parameters/Groups & A (Control) & $\mathrm{B}\left(\mathrm{CdCl}_{2}\right.$ only $)$ & C (HMETV only) & $\mathrm{D}(\mathrm{Cd}+\mathrm{HMETV})$ \\
\hline PCV (\%) & $40.33 \pm 1.20^{\mathrm{a}}$ & $31.00 \pm 2.00^{\mathrm{b}}$ & $38.33 \pm 2.03^{\mathrm{a}}$ & $34.33 \pm 1.45^{\mathrm{b}}$ \\
\hline $\mathrm{Hb}(\mathrm{g} / \mathrm{dl})$ & $16.44 \pm 1.77^{\mathrm{a}}$ & $13.60 \pm 2.00^{\mathrm{b}}$ & $14.32 \pm 0.44^{\mathrm{b}}$ & $14.71 \pm 0.65^{\mathrm{b}}$ \\
\hline $\mathrm{RBC}\left(\times 10^{6} / \mathrm{ml}\right)$ & $9.13 \pm 0.50^{\mathrm{a}}$ & $5.85 \pm 0.65^{b}$ & $7.21 \pm 0.44^{\mathrm{a}}$ & $6.03 \pm 0.82^{b}$ \\
\hline WBC $\left(\times 10^{3} / \mu \mathrm{l}\right)$ & $1.48 \pm 0.23^{\mathrm{a}}$ & $2.00 \pm 0.45^{\mathrm{a}}$ & $1.33 \pm 0.19^{\mathrm{a}}$ & $1.53 \pm 0.13^{\mathrm{a}}$ \\
\hline Basophils $\left(\times 10^{3} / \mu \mathrm{l}\right)$ & $0.017 \pm 0.01^{\mathrm{a}}$ & $0.006 \pm 0.00^{\mathrm{a}}$ & $0.008 \pm 0.00^{\mathrm{a}}$ & $0.028 \pm 0.01^{\mathrm{a}}$ \\
\hline Eosinophil $\left(\times 10^{3} / \mu \mathrm{l}\right)$ & $0.02 \pm 0.00^{\mathrm{a}}$ & $0.02 \pm 0.01^{\mathrm{a}}$ & $0.02 \pm 0.01^{\mathrm{a}}$ & $0.01 \pm 0.00^{\mathrm{a}}$ \\
\hline Neutrophils $\left(\times 10^{3} / \mu \mathrm{l}\right)$ & $0.37 \pm 0.04^{\mathrm{a}}$ & $1.14 \pm 0.30^{\mathrm{b}}$ & $0.36 \pm 0.05^{\mathrm{a}}$ & $0.94 \pm 0.19^{\mathrm{b}}$ \\
\hline $\operatorname{Monocytes}\left(\times 10^{3} / \mu \mathrm{l}\right)$ & $0.02 \pm 0.00^{\mathrm{a}}$ & $0.04 \pm 0.01^{\mathrm{a}}$ & $0.03 \pm 0.00^{\mathrm{a}}$ & $0.03 \pm 0.00^{\mathrm{a}}$ \\
\hline $\begin{array}{c}\text { Lymphocytes } \\
\left(\times 10^{3} / \mu \mathrm{l}\right)\end{array}$ & $1.05 \pm 0.18^{\mathrm{a}}$ & $0.80 \pm 0.14^{\mathrm{a}}$ & $0.91 \pm 0.22^{a}$ & $0.53 \pm 0.07^{\mathrm{a}}$ \\
\hline $\operatorname{ALT}(\mathrm{U} / \mathrm{L})$ & $30.31 \pm 9.09^{a}$ & $52.01 \pm 8.23^{\mathrm{a}}$ & $36.18 \pm 1.60^{a}$ & $35.53 \pm 4.48^{\mathrm{a}}$ \\
\hline $\operatorname{ALP}(\mathrm{U} / \mathrm{L})$ & $86.03 \pm 14.82^{a}$ & $100.00 \pm 15.87^{\mathrm{a}}$ & $80.66 \pm 5.59^{a}$ & $95.12 \pm 5.84^{\mathrm{a}}$ \\
\hline $\mathrm{AST}(\mathrm{U} / \mathrm{L})$ & $59.40 \pm 0.90^{a}$ & $69.24 \pm 2.21^{\mathrm{ab}}$ & $48.17 \pm 9.39^{\mathrm{ac}}$ & $65.84 \pm 2.94^{\mathrm{ab}}$ \\
\hline Bilirubin $((\mu \mathrm{mol} / \mathrm{L})$ & $0.06 \pm 0.04^{\mathrm{b}}$ & $0.41 \pm 0.06^{\mathrm{a}}$ & $0.07 \pm 0.02^{\mathrm{b}}$ & $0.16 \pm 0.04^{\mathrm{b}}$ \\
\hline Total Protein $(\mathrm{g} / \mathrm{l})$ & $9.44 \pm 1.25^{\mathrm{b}}$ & $6.47 \pm 1.71^{\mathrm{b}}$ & $13.30 \pm 0.67^{\mathrm{a}}$ & $7.12 \pm 1.07^{b}$ \\
\hline $\operatorname{Albumin}(\mathrm{g} / \mathrm{l})$ & $2.88 \pm 0.56^{a}$ & $2.63 \pm 0.20^{\mathrm{a}}$ & $3.99 \pm 0.81^{\mathrm{a}}$ & $2.73 \pm 1.12^{\mathrm{a}}$ \\
\hline Creatinine $(\mu \mathrm{mol} / \mathrm{L})$ & $0.84 \pm 0.08^{\mathrm{a}}$ & $1.20 \pm 0.05^{\mathrm{a}}$ & $1.04 \pm 0.14^{\mathrm{a}}$ & $1.07 \pm 0.17^{\mathrm{a}}$ \\
\hline
\end{tabular}


Cadmium intoxication also led to a significant $(\mathrm{p}<0.05)$ reduction in SOD and CAT activity with increased MDA concentration while cadmium plus HMETV significantly increased the activity of CAT and SOD with significant $(\mathrm{p}<0.05)$ decrease in the MDA level in liver and kidney tissues when compared with the group treated with cadmium only (Table 2 ).

Table 2. Hepatic and renal oxidative stress marker and antioxidant enzyme activity of the experimental groups of rats

\begin{tabular}{|c|c|c|c|c|}
\hline Groups & Tissue & MDA (nmol/g.tissue) & SOD (U/g.tissue) & CAT (U/g.tissue) \\
\hline \multirow{2}{*}{ A (Control) } & Liver & $30.92 \pm 1.10^{\mathrm{d}}$ & $28.08 \pm 1.65^{\mathrm{a}}$ & $72.38 \pm 1.17^{\mathrm{a}}$ \\
& Kidney & $112.65 \pm 1.62^{\mathrm{b}}$ & $65.55 \pm 2.59^{\mathrm{a}}$ & $44.02 \pm 1.24^{\mathrm{a}}$ \\
\hline \multirow{2}{*}{$\mathrm{B}\left(\mathrm{CdCl}_{2}\right.$ only) } & Liver & $74.35 \pm 1.71^{\mathrm{a}}$ & $8.83 \pm 1.00^{\mathrm{d}}$ & $46.44 \pm 1.00^{\mathrm{d}}$ \\
& Kidney & $221.20 \pm 5.86^{\mathrm{a}}$ & $28.81 \pm 1.10^{\mathrm{d}}$ & $20.49 \pm 0.87^{\mathrm{c}}$ \\
\hline \multirow{2}{*}{ C (HMETV only) } & Liver & $28.62 \pm 0.62^{\mathrm{d}}$ & $26.03 \pm 1.30^{\mathrm{a}}$ & $70.07 \pm 1.72^{\mathrm{a}}$ \\
& Kidney & $107.56 \pm 2.03^{\mathrm{b}}$ & $60.43 \pm 0.71^{\mathrm{a}}$ & $43.70 \pm 1.03^{\mathrm{a}}$ \\
\hline \multirow{2}{*}{ D (CdCl + HMETV) } & Liver & $28.15 \pm 0.83^{\mathrm{d}}$ & $25.61 \pm 1.46^{\mathrm{a}}$ & $68.96 \pm 0.41^{\mathrm{a}}$ \\
& Kidney & $105.16 \pm 1.62^{\mathrm{b}}$ & $58.61 \pm 2.42^{\mathrm{a}}$ & $42.43 \pm 0.01^{\mathrm{a}}$ \\
\hline
\end{tabular}

The values (mean \pm SE) $(n=5)$ bearing different superscripts in the same column differ significantly at $\mathrm{p}<0.05$.

Significance was determined by one-way ANOVA followed by Post-hoc Test).

The histopathological examination of the liver in the control group of rats showed normal histoarchitecture as the hepatocytes had its characteristic prominent nucleus and nucleolus. These were arranged in anastomosing plates and cords radiating from visible central vein separated by sinusoids. However, Cd administration in group $B$ led to severe vacuolar degeneration of hepatocytes but mild degenerative changes in group D (Cd + HMETV) compared to the control (group A) and HMETV treated group C which had normal histological features (Figure 1).
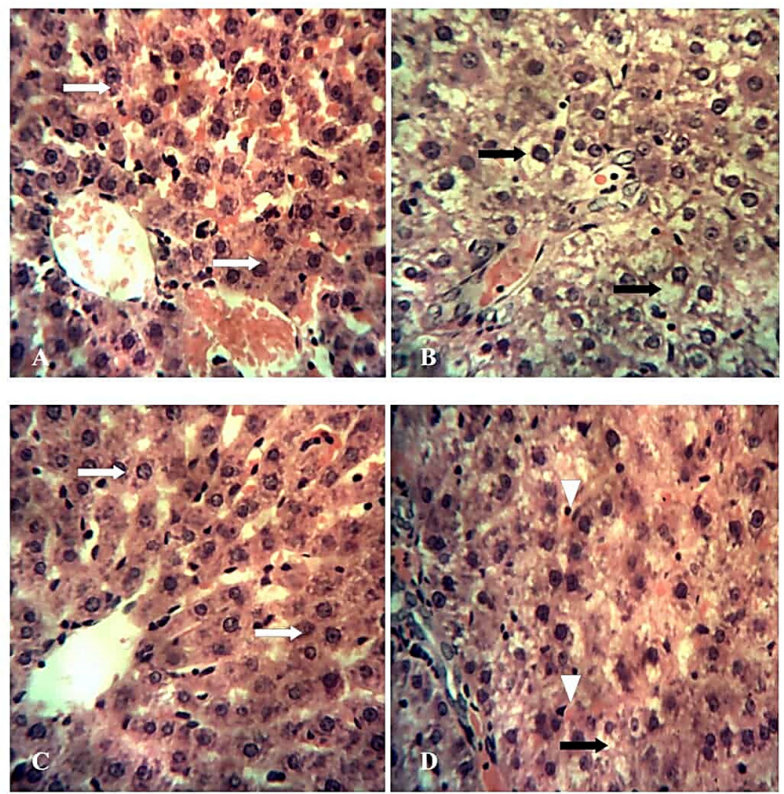

Figure 1. Photomicrograph of the liver from groups A (control) and C (500mg/kg HMETV) showing apparently normal hepatocytes (white arrows)

Note the moderate vacuolar degeneration of hepatocytes in group B ( $\mathrm{CdCl}_{2}$ at $3 \mathrm{mg} / \mathrm{kg}$-black arrows) and dilated sinusoids with hemosiderin (arrowheads) and mild vacuolar degeneration of hepatocytes (black arrows) in group D $\left(\mathrm{CdCl}_{2}\right.$ at $3 \mathrm{mg} / \mathrm{kg}+500 \mathrm{mg} / \mathrm{kg}$ HMETV$)$. HE x 400 . 
The kidney sections of rats from the control (group A), showed a normal structure of renal cortex and medulla comprising of tubules and renal corpuscle consisting of a tuft of capillaries (the glomerulus) surrounded by a double-walled epithelial capsule called Bowman's capsule which is separated by the urinary or Bowman's space. The same normal features were observed in rats treated with HMETV only (group C). However, the groups treated with cadmium only (group B) showed mild degeneration of the renal tubules compared to HMETV + Cd treated group D which had only focal area of tubular epithelial cell apoptosis (Figure 2).

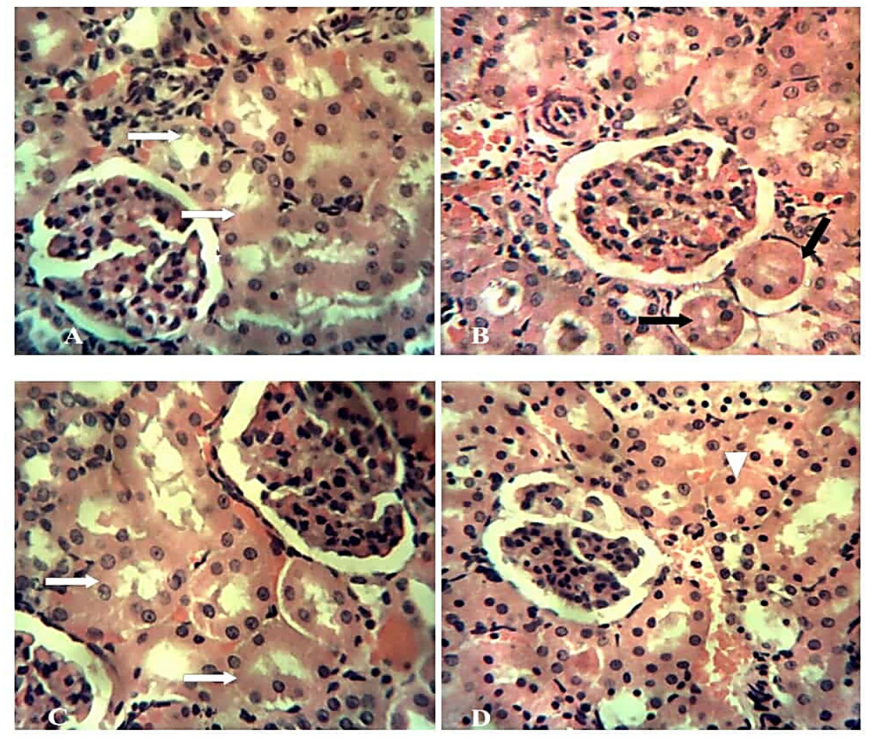

Figure 2. Photomicrograph of the kidney from groups A (control) and C (500mg/kg HMETV) rats showing the renal tubules (white arrows) with no observable histological change while groups $\mathrm{B}\left(\mathrm{CdCl}_{2}\right.$ at $3 \mathrm{mg} / \mathrm{kg}$ ) shows mild renal tubular degeneration (black arrows)

Note the focal area of tubular epithelial cell apoptosis (arrowhead) in group D $\left(\mathrm{CdCl}_{2}-3 \mathrm{mg} / \mathrm{kg}+500 \mathrm{mg} / \mathrm{kg}\right.$ HMETV). HE $x 400$.

\section{Discussion}

Cadmium exerts its known toxic effects on the various organs of the body like the kidney and liver through its induction of oxidative stress (Dzobo and Naik, 2013; Kumar et al., 2019). Thus, this study was undertaken to evaluate the possible ameliorative effect of hydromethanol extract of Thymus vulgaris on hepatorenal toxicity induced by cadmium in male rats. The reduction in erythrocytic indices in this study shows that cadmium induces anemia and this was ameliorated following treatment with HMETV. This may be due to increased rate of erythrocyte destruction, leading to a decrease in $\mathrm{RBC}$ count and an expected decrease in PCV level and $\mathrm{Hb}$ content as was demonstrated in earlier reports (Ognjanovic et al., 2003; Mladenovic' et al., 2014). The presence of $\mathrm{Cd}$ in the bloodstream is also known to cause iron deficiency and decrease in the amount of $\mathrm{Hb}$, as acute $\mathrm{Cd}$ intoxication induces lipid peroxidation in erythrocytes membrane causing erythrocyte haemolysis and resultant anemia (Matovic et al., 2015; Suh et al., 2016). Although, the hemoglobin concentration and RBC count in the HMETV recipient group were reduced, the values were still higher than that of the group treated with $\mathrm{Cd}$ only. However, further research is required to understand the actual effect of HMETV on hematological indices in rats.

In the present study, we observed increased WBC count in cadmium treated group of rats which was associated with neutrophilia and lymphopenia compared to the control and HMETV treated group. This 
is similar to previous reports (Horiguchi and Oguma, 2016; Donmez et al., 2019) and may be due to neutrophil oxidative burst and immunosuppression (Descotes, 1992; Schulte et al., 1994; Dan et al., 2000; Milica et al., 2017). Neutrophilia is also known to be associated with drug or chemical induced stress in animals (Pruett et al., 2007). The changes observed in serum activity of liver enzymes (ALT, ALP, and AST) were similar to previous work which reported significant increase in ALT and AST of cadmium treated rats (Haidri and Malik, 2016; Oyinloye et al., 2016). This was confirmed by the liver histopathology of the cadmium treated group of rats.

The present result also showed that total protein and albumin were decreased with concurrent increase in creatinine level in cadmium treated groups compared to the control and HMETV treated groups. This was confirmed by the renal histopathological lesions seen in this study which may have resulted in proteinuria, hypoproteinemia and increased serum creatinine. Scientific reports have shown that many herbs and spices are effective in ameliorating toxicant induced oxidative stress (Wojdylo et al., 2007). In this study, the administration of cadmium $(3 \mathrm{mg} / \mathrm{kg})$ led to a significant increase in liver and kidney MDA concentration compared to the control group whereas the MDA concentration in the HMETV $500 \mathrm{mg} / \mathrm{kg}+$ cadmium groups were significantly lower compared to the cadmium treated group. MDA is used as a marker of tissue injury as it is a secondary product of lipid peroxidation in tissues (Gulcin, 2012; Gulcin and Beydemir, 2013).

The results of this study showed that HMETV reduced MDA concentration in the liver and kidney tissues. Antioxidants enzymes such as SOD and CAT play an important role by protecting cells against oxidative damage. In this study, cadmium significantly reduced the antioxidant activities of SOD and CAT in the liver and kidney tissues compared to the control group. This was ameliorated following treatment with HMETV $500 \mathrm{mg} / \mathrm{kg}$ which led to an increase in antioxidant enzyme activities observed in the rat liver and kidney tissues. This is in agreement with previous reports where thymus oil treatment was observed to protect tissues against oxidative stress and induce an increase in antioxidant enzyme activities (Sathiavelu et al., 2009; Pushpavalli et al., 2010).

The cadmium induced histopathological lesions in the liver and kidney as observed in this study were similar to previous reports (El-Refaiy and Eissa, 2013). However, the suppressive effects of the thymus vulgaris extract on cadmium induced tissue damage was further proven by the significant restoration of liver and kidney histology.

\section{Conclusions}

This study has shown that Thymus vulgarishas a protective effect against cadmium induced hepatorenal injury through the suppression of oxidative stress.

\section{Authors' Contributions}

RIO, CUC and TNE were in involved in research conceptualization, supervision; project administration; validation; visualization; writing - original draft; writing - review and editing while HEU and EUU were involved in data curation; formal analysis; investigation; methodology; resources and software. All authors read and approved the final manuscript.

Ethical approval (for researches involving animals or humans)

This study was approved by the Animal Welfare and Ethics Committee of the Faculty of Veterinary Medicine, University of Nigeria, Nsukka (FVM2020117). 


\section{Acknowledgements}

The histological slides in this research work were kindly prepared by the technical staff of the Department of Veterinary Pathology and Microbiology, Faculty of Veterinary Medicine, University of Nigeria, Nsukka.

\section{Conflict of Interests}

The authors declare that there are no conflicts of interest related to this article.

\section{References}

Hadwan MH (2018). Simple spectrophotometric assay for measuring catalase activity in biological tissues. BMC Biochemistry 19(7):1-8. https://doi.org/10.1186/s12858-018-0097-5

Bancroft JD, Gamble M (2002). Theory and practice of histological techniques. Edinburgh: Churchill Livingstone.

Blass KG, Thiebert RJ, Lam LK (1974). A study of the mechanism of the Jaffe reaction. Journal of Clinical Chemistry and Clinical Biochemistry 12(7):336-343. https://doi.org/10.1515/cclm.1974.12.7.336

Rahimzadeh RM, Rahimzadeh RM, Kazemi S, Moghadamnia AA (2017). Cadmium toxicity and treatment: An update. Caspian Journal of Internal Medicine 8(3):135-145. https://doi.org/10.22088/cjim.8.3.135

Thrall MA, Weiser MG (2002). Hematology. In: Hendrix CM (Ed). Laboratory Procedures for Veterinary Technicians, 4th edn. Mosby, Missouri pp 29-74.

Dan G, Lall SB, Rao DN (2000). Humoral and cell mediated immune response to cadmium in mice. Drug and Chemical Toxicology 23(2):349-360. https://doi.org/10.1081/DCT-100100120

Daud D, Fekery NFM, Hashim N (2017). Reproductive health of rats with benign prostatic hyperplasia following Cosmos caudatus ethanolic extracts consumption. Journal of Applied Pharmaceutical Science 7(6):202-205. https://doi.org/10.7324/JAPS.2017.70630

Descotes J (1992). Immunotoxicology of cadmium. IARC Scientific Publications 118:385-390.

Donmez HH, Donmez N, Kisadere I, Undag I (2019). Protective effect of quercetin on some hematological parameters in rats exposed to cadmium. Biotechnic and Histochemistry 94(5):381-386. https://doi.org/10.1080/10520295.2019.1574027

Doumas BT, Watson WA, Biggs HG (1997). Albumin standards and the measurement of serum albumin with bromcresol green. 1971. Clinica Chimica Acta 258(1):21-30. https://doi.org/10.1016/s0009-8981(96)06447-9

Dzobo K, Naik YS (2013). Effect of selenium on cadmium-induced oxidative stress and esterase activity in rat organs. South African Journal of Science 109(5-6):1-8. https://doi.org/10.1590/sajs.2013/965

El-Refaiy AI, Eissa FI (2013). Histopathology and cytotoxicity as biomarkers in treated rats with cadmium and some therapeutic agents. Saudi Journal of Biological Sciences 20(3):265-280. https://doi.org/10.1016/j.sjbs.2013.02.004

El-Habit OH, Abdel Moneim AE (2014). Testing the genotoxicity, cytotoxicity and oxidative stress of cadmium and nickel and their additive effect in male mice. Biological Trace Element Research 159(1-3):364-372. https://doi.org/10.1007/s12011-014-0016-6

El-Nekeety AA, Mohamed SR, Hathout AS, Hassan NS, Aly SE, Abdel-Wahhab MA (2011). Antioxidant properties of Thymus vulgaris oil against aflatoxin-induce oxidative stress in male rats. Toxicon 57(7-8):984-991. https://doi.org/10.1016/j.toxicon.2011.03.021

Gulcin I, Beydemir S (2013). Phenolic compounds as antioxidants: carbonic anhydrase isoenzymes inhibitors. MiniReviews in Medicinal Chemistry 13(3):408-430. https://doi.org/10.2174/1389557511313030009

Gülçin I (2012). Antioxidant activity of food constituents: an overview. Archives of Toxicology 86(3):345-391. https://doi.org/10.1007/s00204-011-0774-2

Haidry MT, Malik A (2016). Therapeutic effects of Cassia angustifolia in cadmium induced hepatotoxicity assay conducted in male albino rats. Bulletin of Environmental Studies 1(2):39-42. 
Horiguchi H, Oguma E (2016). Acute exposure to cadmium induces prolonged neutrophilia along with delayed induction of granulocyte colony-stimulating factor in the livers of mice. Archives of Toxicology 90(12):3005-3015. https://doi.org/10.1007/s00204-016-1661-7

Huff J, Lunn RM,Waalkes MP, Tomatis L, Infante PF (2007). Cadmium-induced cancers in animals and in humans. International Journal of Occupational and Environmental Health 13(2):202-212. https://doi.org/10.1179/oeh.2007.13.2.202

IARC (2012). Evaluation of carcinogenic risks to humans: International Agency for Research on Cancer. Lyon, France. Retrieved 2020 January 1 from https://monographs.iarc.fr/wp content/uploads/2018/06/mono100E.pdf

Higgins T, Beutler E, Doumas BT (2008). Measurement of haemoglobin in blood. In: Burtis CA, Ashwood ER, Bruns DE (eds), Tietz Fundamentals of Clinical Chemistry, 6th edn. Sanders Elsevier, Missouri, pp 524-525.

Kumar A, Pandey R, Siddiqi NJ, Sharma B (2019). Oxidative stress biomarkers of cadmium toxicity in mammalian systems and their distinct ameliorative strategy. Journal of Applied Biotechnology and Bioengineering 6(3):126135.

Johnson AM (2008). Aminoacids and proteins. In: Burtis CA, Ashwood ER, Bruns DE (Eds). Tietz Fundamentals of Clinical Chemistry, Saunders Elsevier, Missouri pp 206-316.

Matović V, Buha A, Đukić-Ćosić D, Bulat Z (2015). Insight into the oxidative stress induced by lead and/or cadmium in blood, liver and kidneys. Food and Chemical Toxicology 78:130-140. https://doi.org/10.1016/S0278-6915 (15)00074-5

Milica GP, Milos MM, Branka IO, Zorica SS (2017). Antioxidative and haematoprotective activity of coenzyme Q10 and vitamin E against cadmium-induced oxidative stress in Wistar rats. Toxicology and Industrial Health 33(10):746756. https://doi.org/10.1177/0748233717725480

Mladenovic J, Ognjanovic B, Đordevic N, Matić M, Knežević V, Štajn A, Saičić Z (2014). Protective effects of estradiol against cadmium induced changes in blood parameters and oxidative damage in rats. Archives of Industrial Hygiene and Toxicology 65(1):37-46. https://doi.org/10.2478/10004-1254-65-2014-2405

Mouihs JM, Thevenod F (2010). New perspectives in cadmium toxicity: an introduction. Biometals 23(5):763-768. https://doi.org/10.1007/s10534-010-9365-6

NRC (2011). National Research Council Committee for the Update of the Guide for the Care and Use of Laboratory Animals. Guide for the Care and Use of Laboratory Animals. 8th edition. Washington (DC): National Academies Press (US).

Nishikimi M, Appaji N, Yagi K (1972). The occurrence of superoxide anion in the reaction of reduced phenazine methosulfate and molecular oxygen. Biochemical Biophysical Research Communication 46(2):849-854. https://doi.org/10.1016/S0006-291X(72)80218-3

Nordberg GF, Fowler B, Nordberg M (2014). Handbook on the toxicology of metals. $4^{\text {th }}$ Ed. Elsevier: Academic Press, New York.

Ocaña A, Reglero G (2012). Effects of thyme extract oils (from Thymus vulgaris, Thymus zygis, and Thymus hyemalis) on cytokine production and gene expression of oxLDL-Stimulated THP-1-Macrophages. Journal of Obesity 2012:104706. https://doi.org/10.1155/2012/104706

OECD (2002). Test No. 423: Acute Oral toxicity - Acute Toxic Class Method, Organization for Economic Cooperation and Development Guidelines for the Testing of Chemicals, Section 4, OECD Publishing (in Paris). Retrieved 2019 April 12 from https://doi.org/10.1787/9789264071001-en

Ohkawa H, Ohishi N, Yagi K (1979). Assay for lipid peroxides in animal tissues by thiobarbituric acid reaction. Analytical Biochemistry 95(2):351-358. https://doi.org/10.1016/0003-2697(79)90738-3

Ognjanovic BI, Pavlovic SZ, Maletic SD, Zikić RV, Stajn AS, Radojicić RM, ... Petrović VM (2003). Protective influence of vitamin $\mathrm{E}$ on antioxidant defense system in the blood of rats treated with cadmium. Physiological Research 52(5):563-570.

Oyinloye BE, Ajiboye BO, Ojo OA, Nwozo SO, Kappo AP (2016). Cardio-protective and antioxidant influence of aqueous extracts from Sesamum indicum seeds on oxidative stress induced by cadmium in wistar rats. Pharmacognosy Magazine 12(46):170-174.

Ponnusamy M, Pari L (2011). Protective role of diallyl tetrasulfide on cadmium-induced testicular damage in adult rats: A biochemical and histological study. Toxicology and Industrial Health 27(5):407-416. https://doi.org/10.1177/0748233710387633 
Pruett SB, Hebert P, Lapointe J, Reagan ML, Kawabata TT (2007). Characterization of the action of drug-induced stress responses on the immune system: Evaluations of biomarkers for drug-induced stress in rats. Journal of Immunotoxicology 4(1):25-38. https://doi.org/10.1080/15476910601115150

Pushpavalli G, Veeramani C, Pugalendi KV (2010). Influence of chrysin on hepatic marker enzymes and lipid profile against D-galactosamine-induced hepatotoxicity rats. Food and Chemical Toxicology 48(6):1654-1659. https://doi.org/10.1016/j.fct.2010.03.040

Colville J (2002). Blood chemistry. In: Hendrix CM (Ed). Laboratory procedures for Veterinary Technicians, 4th edn. Mosby, St Louis pp 75-103.

Sathiavelu J, Senapathy GJ, Devaraj R, Namasivayam N (2009). Hepatoprotective effect of chrysin on prooxidantantioxidant status during ethanol-induced toxicity in female albino rats. The Journal of Pharmacy and Pharmacology 61(6):809-817. https://doi.org/10.1211/jpp/61.06.0015

Schulte S, Mengel K, Gatke U, Friedberg KD (1994). No influence of cadmium on the production of specific antibodies in mice. Toxicology 93(2-3):263-268. https://doi.org/10.1016/0300-483x(94)90083-3

Satyal P, Murray BL, McFeeters RL, Setzer WN (2016). Essential oil characterization of Thymus vulgaris from various geographical locations. Foods 5(4):70. https://doi.org/10.3390/foods5040070

Suh YJ, Lee JE, Lee DH, Yi HG, Lee MH, Kim CS, ... Kim SK (2016). Prevalence and relationships of iron deficiency anemia with blood cadmium and vitamin levels in Korean women. Journal of Korean Medical Science 31(1):2532. https://doi.org/10.3346/jkms.2016.31.1.25

Vigo E, Cepeda A, Gualillo O, Perez-Fernandez R (2004). In vitro anti-inflammatory effect of Eucalyptus globulus and Thymus vulgaris: nitric oxide inhibition in J774A.1 murine macrophage. The Journal of Pharmacy and Pharmacology 56(2):257-263. https://doi.org/10.1211/0022357022665

Wojdylo A, Oszmianski J, Czemerys R (2007). Antioxidant activity and phenolic compounds in 32 selected herbs. Food Chemistry 105(3):940-949. https://doi.org/10.1016/j.foodchem.2007.04.038

Zarei L, Shahrooz R (2019). Protective effects of Cornus mas fruit extract on methotrexate-induced alterations in mice testicular tissue: Evidences for histochemical and histomorphometrical changes in an animal model study. Veterinary Research Forum 10 (4):307-313. https://doi.org/10.30466/vrf.2019.69516.1955
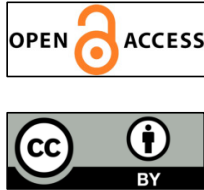

The journal offers free, immediate, and unrestricted access to peer-reviewed research and scholarly work. Users are allowed to read, download, copy, distribute, print, search, or link to the full texts of the articles, or use them for any other lawful purpose, without asking prior permission from the publisher or the author.

License - Articles published in Notulae Scientia Biologicae are Open-Access, distributed under the terms and conditions of the Creative Commons Attribution (CC BY 4.0) License.

(c) Articles by the authors; SHST, Cluj-Napoca, Romania. The journal allows the author(s) to hold the copyright/to retain publishing rights without restriction. 